\title{
0 estágio curricular supervisionado em tempos de pandemia: experiência em um curso de ciências biológicas
}

\author{
Dafne Fonseca Alarcon ${ }^{1}$ \\ André Ary Leonel ${ }^{2}$ \\ José André Angotti ${ }^{3}$
}

\section{RESUMO}

O objetivo do artigo é contribuir para a formação de professores de Ciências Biológicas a partir das experiências vivenciadas durante o Estágio Curricular Supervisionado Remoto em 2020. Nesse ano, a educação teve que se adaptar, e com isso novos temas foram abordados sobre o Ensino Remoto, apontado como uma alternativa viável para dar continuidade aos estudos e enfrentar a situação crítica vivenciada pela população mundial no período de pandemia. Nesse contexto, escolas e universidades sofreram com mudanças radicais no que se refere ao processo de ensino e aprendizagem, bem como ao uso intensivo das Tecnologias Digitais de Informação e Comunicação (TDIC). Como resultado, são apresentados os relatos de experiência dos estagiários e as diretrizes para o desenvolvimento do estágio em tempo de Ensino Remoto Emergencial.

Palavras-chave: Estágio Remoto. Formação de Professores de Ciências Biológicas. Tecnologias Digitais de Informação e Comunicação (TDIC).

\footnotetext{
${ }^{1}$ dafnefa@gmail.com - Universidade do Estado de Santa Catarina

2 andre.leonel@ufsc.br - Universidade Federal de Santa Catarina

3 -zeangotti@gmail.com - Universidade Federal de Santa Catarina
} 


\section{The supervised curricular internship in pandemic times: experience in a biological science course}

\section{ABSTRACT}

The objective of this article is to contribute to Biological Sciences teacher education based on the innovative experiences lived during the Remote Supervised Curricular Internship in 2020. Therefore, education had to adapt and new topics were addressed about Remote Education, as an alternative to continue studies and remedy the drastic situation experienced by the world population. In this context, schools and universities have suffered from radical changes with regard to the teaching and learning process, including the intensive use of Digital Information and Communication Technologies. As a result, the experience reports of some of the trainees are presented and, based on the experience reported, a table with guidelines for the development of the internship in the time of Emergency Remote Teaching is presented.

Keywords: Remote Internship. Biological Science Teacher Education. Digital Information and Communication Technology (DICT). 


\section{INTRODUÇÃO}

O ano de 2020 foi marcado por uma situação gravíssima de saúde pública em termos globais. Essa situação modificou o modo de vida de toda a população existente no planeta. Quase todo o mundo vivenciou um momento de isolamento que, literalmente, modificou radicalmente sua rotina. Para Senhoras (2020), os impactos negativos da pandemia da COVID-19 não se manifestam apenas em um problema epidemiológico para 188 países atingidos, "mas antes geram um efeito cascata em uma série de atividades humanas frente às respostas de isolamento social vertical e horizontal implementadas pelos diferentes países" (SENHORAS, 2020, p. 02). Diante de um cenário emergencial, a educação precisou rever suas práticas pedagógicas e se adaptar às novas e inovadoras formas e métodos de ensinar e aprender, por meio das Tecnologias Digitais da Informação e Comunicação (TDIC).

Professores e estudantes tiveram que se adaptar a uma nova realidade, com a qual todo processo de ensino e aprendizagem estaria submetido a alguma prática de mediação pedagógica e tecnológica, de compartilhamento de informações e conhecimentos por meio de uma tela de computador ou smartphone com texto ou imagem digital. Nesse contexto, não havia mais quaisquer possibilidades de encontro presencial, devido à disseminação do novo coronavírus que se alastrou por todo o planeta.

De acordo com Senhoras (2020), professores e estudantes foram afetados em todas as fases do ciclo pandêmico, acentuando as assimetrias educacionais pré-existentes, conforme as especificidades, em função tanto da falta de trilhas de aprendizagem alternativas à distância quanto das lacunas de acessibilidade desses sujeitos às TDIC. Assim, a partir dessa situação emergencial, novas práticas tiveram que ser repensadas e planejadas a fim de dar continuidade às atividades educativas nas escolas e no Ensino Superior. Diante dessa realidade, um dos maiores desafios enfrentados foi o desenvolvimento dos estágios supervisionados nos cursos de Licenciatura, nos quais há o compromisso com a formação de professores para atuar na Educação Básica.

Sendo assim, considerando o contexto do Ensino Remoto Emergencial (ERE), foi possível repensar a disciplina de estágio e contribuir para a criação de novas práticas pedagógicas na formação de professores de Ciências Biológicas a partir do uso intensivo das TDIC no processo de ensino e aprendizagem.

\section{O ESTÁGIO CURRICULAR SUPERVISIONADO EM TEMPOS DE PANDEMIA}

O estágio é uma etapa significativa e determinante para o estudante licenciando, pois apresenta diferentes concepções de docência ao relacionar teoria e prática educativa. Esse campo do conhecimento pedagógico pode ser compreendido como uma disciplina que aproxima e contextualiza a realidade da escola a ser observada e pesquisada com o professor-pesquisador em formação. Essa aproximação contribui de forma ampla e diversificada, o que significa efetivamente estar em sala de aula, observar, planejar e intervir no espaço educativo. 
De acordo com Zimmermann e Bertani (2003), o estágio promove a ligação entre a teoria e a prática ao articular as disciplinas didático-pedagógicas com as de cunho específico. Assim, a "função dessa disciplina é, portanto, a de integrar os ambientes escolares e acadêmicos articulando, portanto, os conteúdos específicos e didáticos" (ZIMMERMANN; BERTANI, 2003, p. 54). Dessa maneira, é na disciplina de estágio que o docente em formação tem a oportunidade de articular todos os saberes envolvidos na prática docente. "Supõe que se busque novo conhecimento na relação entre as explicações existentes e os dados novos que a realidade impõe e que são percebidos na postura investigativa" (PIMENTA; LIMA, 2010, p. 46).

Para Lima e Pimenta (2006), o estágio se constitui como um campo de conhecimento, o que significa atribuir-lhe um estatuto epistemológico que supera sua tradicional redução à atividade prática instrumental. Enquanto campo de conhecimento, o estágio se produz na interação dos cursos de formação com o campo social, no qual se desenvolvem as práticas educativas. Nesse sentido, o estágio poderá se constituir em atividade de pesquisa; os mesmos autores ainda acrescentam que o estágio sempre foi identificado como a parte prática dos cursos de formação de profissionais em geral, em contraposição à teoria. Não é raro ouvir dos alunos que concluem seus cursos se referirem a estes como "teóricos"; que a profissão se aprende "na prática"; que certos professores e disciplinas são demasiados "teóricos"; que "na prática a teoria é outra". Os supracitados autores reforçam ainda que a superação da dicotomia entre teoria e prática nos cursos de Licenciatura não ajuda em nada na formação do profissional da educação, pois "o exercício de qualquer profissão é prático, no sentido de que se trata de aprender a fazer algo ou ação" (LIMA; PIMENTA, 2006, p. 6).

Em se tratando de uma atividade de pesquisa, o estágio exige do estudante uma elevada dedicação e sistematização em campo, a partir de estudos teórico-metodológicos, análise de contexto, observação participante, planejamento, intervenção docente e avaliação. A pesquisa em campo possibilita o desenvolvimento de um olhar crítico e sensível das dinâmicas existentes em sala de aula, onde a presença e o olhar atento legitimam a realidade social em que o ensino se processa. "Só podemos olhar o outro e sua história se temos conosco mesmo uma abertura de aprendiz que observa e se estuda em sua própria história." (WEFFORT, 1997, p. 1-2). Assim, a experiência do estágio representa para o estudante de licenciatura uma primeira aproximação de seu campo de atuação profissional, no qual deverá realizar um trabalho de articulação e síntese entre teoria e prática.

Com a pandemia, esse quadro se modificou radicalmente. 0 que antes era realizado na escola como local oportuno para o aprendizado do futuro professor de ciências, agora passa a ser mediado obrigatoriamente pelas TDIC. No âmbito dessa nova realidade, está a percepção de que o estudante precisa ser capaz de responder mais às exigências de um profissional crítico, reflexivo, pesquisador e capaz de adaptar suas práticas pedagógicas aliadas ao uso e aplicação das TDIC. 


\subsection{O Ensino Emergencial Remoto na formação de professores}

A Educação a Distância (EaD) já é uma realidade no país, contando com uma quantidade considerável de alunos matriculados na modalidade. De acordo com o Censo da Educação Superior de 2019 (BRASIL, 2019), foram mais de 1 milhão e meio de matrículas, com um crescimento de $379 \%$, distribuídas em várias instituições públicas e privadas, apresentando uma larga experiência e com significativo aporte teórico e prático construído em torno da área. Por sua vez, o ERE emergiu com grande força em 2020, e, em muitos casos, até de forma forçada em consequência da pandemia. Assim, para que fosse possível dar continuidade aos estudos e impulsionar a educação no país, essa modalidade educacional tornou-se referência em todas as escolas, níveis educacionais e instituições de Ensino Superior. Apesar disso, diferente da EaD, que é desenvolvida, sobretudo, a partir de um processo de planejamento entre todos os agentes envolvidos, em que, a partir dos objetivos formativos, estratégias didático-metodológicas são pensadas e elaboradas de forma criteriosa; o ERE teve que realizar todo esse processo de forma muito aligeirada.

Para Hodges et al. (2020), o ERE surgiu como uma alternativa temporária de oferta de conteúdos curriculares, devido à situação da crise causada pelo coronavírus. Esse modelo educativo envolve o uso de soluções de ensino totalmente remotos para as aulas previamente elaboradas no formato presencial, podendo ser combinadas com momentos híbridos ao longo da crise.

Nessa perspectiva, apesar de carregarem algumas similaridades, a EaD e o ERE possuem características peculiares no que se refere à mediação do ensino por meio do uso das TDIC. Enquanto a EaD envolve toda uma equipe multidisciplinar de apoio para a qualidade do processo de ensino-aprendizagem e desenvolvimento, a médio e longo prazo, bem como estratégias pedagógicas que consideram as dimensões síncronas e assíncronas no aprendizado, com tempo suficiente para o planejamento prévio e a construção de uma sequência didática que contemple os objetivos formativos almejados em cada ação, o Ensino Remoto se caracteriza pela educação on-line emergencial, planejado de forma aligeirada, podendo ser apresentado em tempo semelhante à educação presencial, como a transmissão em horários específicos das aulas dos professores, nos formatos de lives ou transmissão ao vivo para os estudantes (ARRUDA, 2020, p. 266).

Assim, para que o ERE pudesse se concretizar e atender a demanda, todo o planejamento pedagógico precisou ser reestruturado em um curto período de tempo, e professores tiveram que se adaptar a uma nova realidade de uso intensivo das TDIC. Isso demandou a oferta e realização de diversos treinamentos e capacitações para formação de professores, bem como o apoio aos estudantes em isolamento por meio de incentivos - editais de inclusão digital para acesso e apoio financeiro e de infraestrutura à internet e computadores em casa.

Salienta-se ainda que, no caso do Brasil, a implementação do ERE no Ensino Superior conta com número significativamente reduzido de pessoas sem acesso às tecnologias digitais, conforme observado em dados atuais da Pesquisa Nacional por Amostra de Domicílios Contínua (PNAD) (IBGE, 2020). De acordo com os dados apresentados no último trimestre de 2018, o percentual de jovens estudantes, com 14 anos ou mais - Ensino Médio -, que possuem acesso à 
internet ultrapassa 95\% nas regiões Sul, Sudeste e Centro-Oeste; na região Norte, $81 \%$; e na região Nordeste, 86\% (ARRUDA, 2020, p. 266).

Diante desse cenário, a escola, sendo o principal espaço de formação e transformação, precisa problematizar o papel que as TDIC podem exercer na vida das pessoas e promover uma apropriação crítica e criativa, não para aceitá-las ou negá-las, mas para mediar seu uso consciente (LEONEL, 2015). Nesse sentido, em se tratando do contexto escolar, a integração crítica das mídias configura-se como um dos desafios deste tempo. Uma integração, nessa perspectiva, não significa simplesmente a inclusão de novos recursos tecnológicos, mas a superação do uso meramente instrumental, "levando ao desenvolvimento de práticas pedagógicas que instiguem novas leituras e uso destas TDIC, favorecendo novas maneiras de aprender, pensar, agir, comunicar e produzir." (LEONEL, 2015, p. 15).

Logo, mesmo neste cenário de pandemia, ou principalmente em cenários como este, fazse necessário repensar o papel das TDIC e buscar estratégias que possam promover a inclusão e a emancipação dos sujeitos envolvidos no processo formativo. Isso demanda uma leitura crítica de todo este contexto e um olhar para o potencial dessas tecnologias, em "uma educação com as mídias, mas também para as mídias e por meio das mídias” (LAPA; BELLONI, 2012, p. 178).

\section{METODOLOGIA DO ESTÁGIO REMOTO EM CIÊNCIAS BIOLÓGICAS}

As atividades referentes ao estágio das disciplinas de Estágio Curricular Supervisionado em Ciências Biológicas - I e ll foram realizadas nos dois semestres do ano de 2020 em escolas públicas do município de Lages em Santa Catarina (SC). Essa experiência inédita, ao mesmo tempo em que oportunizou o aprendizado sobre o olhar pedagógico e educativo da disciplina, bem como suas potencialidades interdisciplinares, curriculares e tecnológicas, também revelou a frustração na ausência do contato presencial na experiência vivenciada.

Em se tratando de uma experiência on-line e ministrada a distância pelos estudantes de Ciências Biológicas, o fato de não terem acesso ao Ambiente Virtual de Aprendizagem (AVA) da escola, de certa forma, limitou as possibilidades de observação e intervenção, deixando esse momento centrado na comunicação e nas devolutivas das atividades propostas. Tal situação possibilitou - aos alunos e à professora referência -, avaliar todo o processo de ensino e aprendizagem concentrado nos conteúdos abordados e nos objetivos almejados, de forma coletiva e colaborativa.

Mesmo não tendo acesso ao AVA da escola, o processo de ensino-aprendizagem não se limitou a esse recurso, o que facilitou o entendimento por parte dos estagiários quanto à realização da sequência didática e à aplicação dos materiais didáticos produzidos por eles, pois já sabiam de antemão que teriam que utilizar propostas alternativas para comunicação com os estudantes.

Além da leitura de contexto e a observação participante realizada na $1^{\mathrm{a}}$ etapa do estágio, os estagiários também tiveram que planejar e realizar a intervenção docente, ou seja, efetivamente ministrar as aulas planejadas, junto com a professora referência, conduzindo, assim, uma proposta pedagógica compartilhada para realização das aulas remotas, preparando conteúdos e recursos, de acordo com as necessidades apresentadas em cada contexto. Com isso, 
os estudantes de Ciências Biológicas tiveram que alinhar os conteúdos direcionados para o Ensino Fundamental e Ensino Médio aos conteúdos abordados pela professora na escola, bem como, os conteúdos de Ciências da Natureza e suas Tecnologias, apresentados como conteúdos norteadores pela Base Nacional Comum Curricular (BNCC), cujos temas estão associados à Matéria e Energia, Vida e Evolução, Terra e Universo.

O material impresso se apresentou como um recurso alternativo significativo e necessário para as crianças e adolescentes que não tinham possibilidade de acompanhar as aulas síncronas e assíncronas - ao vivo ou gravadas. Por isso, alguns materiais foram gravados em vídeo e podcast, mas também em formato de apostila impressa - material que a escola poderia imprimir e entregar para as famílias e os responsáveis na própria escola, a cada 15 dias.

A seguir é possível identificar detalhadamente as etapas de realização do estágio remoto: (1) Orientação para a leitura de contexto, que contemplou a leitura atenta dos principais documentos orientadores das escolas - BNCC e Projeto Político Pedagógico (PPP); (2) Observação participante, que envolveu a comunicação por e-mail e chat com o professor referência da escola sobre a disciplina e as mediações realizadas com os estudantes do Ensino Fundamental ou Médio; (3) Planejamento docente, que criou um projeto de intervenção, com o qual os estudantes desenvolveram materiais digitais e impressos, bem como as sequências didáticas para aplicação desses materiais; (4) Compreensão do processo de ensino e aprendizagem, que utilizou o AVA Google Classroom -, e foi ministrado pela professora referência, trazendo suas implicações pedagógicas e tecnológicas; (5) Produção de materiais didáticos digitais, que foram utilizados nos encontros síncronos, por meio de videoconferência; (6) Sequência Didática, que propôs as possibilidades de mediação pedagógica e entrega dos materiais e recursos didáticos com base no planejamento e nos objetivos de aprendizagem; (7) Produção do relatório final, que envolveu a avaliação do processo e as devolutivas da professora referência sobre a experiência do estágio remoto; (8) Socialização do estágio, que encerrou o estágio com a apresentação dos trabalhos e os relatos de experiência em formato síncrono.

De modo geral, os materiais didáticos digitais produzidos pelos estagiários foram entregues para a professora, que utilizou a sequência didática como proposta de aula. Assim, as sequências didáticas do Ensino Remoto nas escolas estavam atreladas às aulas síncronas - que tiveram pouca participação -; a gravação de aulas e vídeos complementares - para serem assistidos em diferentes horários -; e a entrega e feedback das atividades propostas que contavam como presença para a criança ou o adolescente.

É importante salientar que, apesar das estatísticas apontadas demonstrarem que a maioria dos adolescentes possuem computador e internet em casa e, portanto, supostamente têm possibilidade de acompanhar as aulas remotas, a realidade se mostrou muito diferente nas escolas públicas.

Nas escolas do município de Lages (SC), onde foram realizados os estágios, a maioria apresentou dificuldades em acompanhar as aulas remotas, ou por não possuírem um computador - muitos só acompanhavam pelo celular, o que dificultou a realização de atividades mais complexas, como escrever textos longos e realizar trabalhos com imagens -, ou por não possuírem uma internet de qualidade com velocidade suficiente para acompanhar os vídeos transmitidos ao vivo. 
Como já salientado, o Estágio Curricular Supervisionado é um momento único na formação docente, pois desafia o estudante a refletir criticamente sobre os conhecimentos assimilados e práticas vivenciadas, relacionando-os à realidade social e à prática pedagógica vivenciada na escola.

O que ocorreu no ano de 2020, porém, foi uma experiência inédita para a prática do estagiário, pois sua atuação estava condicionada à interação remota com o professor regente, sob supervisão e acompanhamento pedagógico de professores e tutores do Centro de Educação a Distância (CEAD) da Universidade do Estado de Santa Catarina (UDESC). Mesmo se tratando de um centro que é referência no Estado de Santa Catarina na modalidade a distância, a situação da pandemia não eximiu o CEAD dos desafios deste tempo, principalmente pelo fato de o curso de Licenciatura em Ciências Biológicas contar com encontros presenciais - portanto, trata-se de um curso blended learning, ou semipresencial -, com a realização dos estágios dentro da escola, contando com o acompanhamento e orientação da equipe pedagógica do CEAD e a supervisão de professores.

Os relatos foram produzidos durante a intervenção pedagógica, momento em que os estagiários puderam descrever e compartilhar suas experiências por meio da ferramenta Diário de Bordo, disponível no AVA Moodle da UDESC/CEAD, apresentando com detalhes as experiências sobre a produção de materiais didáticos, impressos e digitais, bem como, a sequência didática proposta no processo de mediação pedagógica.

No Quadro 1, são apresentados alguns dos relatos dos estagiários do Curso de Licenciatura em Ciências Biológicas durante a intervenção docente no estágio remoto realizado em escolas públicas da cidade de Lages (SC).

Quadro 1: Relatos de experiência no estágio remoto

\begin{tabular}{|l|l|}
\hline ESTAGIÁRIOS (AS) & \multicolumn{1}{c|}{ RELATOS DA EXPERIÊNCIA } \\
\hline Estagiário (a) 1 & $\begin{array}{l}\text { "Fomos motivados a desenvolver um TRABALHO COLABORATIVO com a professora, } \\
\text { realizando atividades como resolução de exercícios, leitura de textos, realização da } \\
\text { chamada. No cenário atual que nos encontramos, relatamos a ansiedade de não } \\
\text { podermos estar presente presencialmente, dificultando ainda mais nossa } \\
\text { devolutiva. Mas foi uma experiência única, no que se reflete na necessidade da } \\
\text { formação de professores preparados para solucionar tais problemas." }\end{array}$ \\
\hline Estagiário (a) 2 & $\begin{array}{l}\text { "Algumas consideraçães foram levantadas na tentativa de motivar os estudantes } \\
\text { como utilização de chamadas por vídeos, diversificando as experiências de } \\
\text { aprendizagem dos estudantes NA ESCOLA, garantindo alguma estabilidade frente } \\
\text { ao cenário de tantas mudanças e percebemos que muitos alunos não participam } \\
\text { das chamadas, dificultando assim as DEVOLUTIVAS e entendimentos." }\end{array}$ \\
\hline Estagiário (a) 3 & $\begin{array}{l}\text { "Em relação a aula preparada por mim que tinha como subtema "CORONAVÍRUS- } \\
\text { O que eu preciso saber?". Realizei um levantamento de informações a respeito da } \\
\text { estrutura viral do SARS- CoV -2, agente etiológico da COVID-19 e montei uma aula } \\
\text { em power point com explanação oral, e análise de imagens e vídeos sobre o } \\
\text { assunto. Ao final propus como atividade a criação de um MODELO EM 3D DO VíRUS } \\
\text { utilizando materiais que os alunos tinham em casa e sua criatividade." }\end{array}$ \\
\hline
\end{tabular}




\begin{tabular}{|l|l|}
\hline ESTAGIÁRIOS (AS) & \multicolumn{1}{c|}{ RELATOS DA EXPERIÊNCIA } \\
\hline Estagiário (a) 4 & $\begin{array}{l}\text { "De forma aprofundada pude entender como a experiência do estágio foi muito } \\
\text { significativa, durante a universidade tive muita dificuldade em compreender os } \\
\text { termos - plano de aula e sequência didática - não compreendia muito bem os } \\
\text { termos e as diferenças e acabava misturando tudo, a vivência do estágio me } \\
\text { possibilitou conhecer a BNCC elaborar um plano de aula e uma sequência didática } \\
\text { da forma correta. Ter essa experiência em tempos de pandemia foi desafiador, pois } \\
\text { nutrimos uma expectativa em relação a prática docente de forma tradicional, essa } \\
\text { adaptação nos mostrou a importância de sermos resilientes e adaptativos as } \\
\text { situações, foi a OPORTUNIDADE DE NOS REINVENTARMOS." }\end{array}$ \\
\hline Estagiário (a) 5 & $\begin{array}{l}\text { "De certa forma foi um pouco frustrante por não ter nenhuma vivência em sala de } \\
\text { aula esse seria o momento para o contato. Mas como estamos vivendo em um } \\
\text { momento atípico, foi preciso nos adaptarmos a essa realidade. O estágio I, já se } \\
\text { deu com a OBSERVAÇÃO À DISTÂNCIA, o que continuou agora na intervenção. } \\
\text { Fomos acolhidas nesse semestre pela professora, uma profissional muito } \\
\text { compreensiva, a mesma sabendo que nenhuma das quatro estagiárias tinha } \\
\text { experiência em sala teve o cuidado de além de fornecer a temática, revisa e orienta } \\
\text { a produção dos planejamentos das aulas." }\end{array}$ \\
\hline Estagiário (a) 6 & $\begin{array}{l}\text { Como as aulas não estavam mais ocorrendo de modo síncrono, apesar do colégio } \\
\text { disponibilizar estrutura para tal momento, devido ao fato da professora não poder } \\
\text { estar presencialmente na escola. A atividade teve que ser adaptada e foi enviada } \\
\text { então somente em forma de questionário para ser respondido pelos alunos. Em } \\
\text { seguida, ela aplicou nossa aula em PPT de forma on-line, de modo assíncrono (aula } \\
\text { gravada, na qual ela explicou de tratar de atividades de estágio e como eles } \\
\text { deveriam proceder para assistir e realizar as atividades) na plataforma Unimestre. } \\
\text { Assim que ela ia recebendo as atividades nos encaminhava para analisarmos os } \\
\text { feedbacks. Nossa maior dificuldade foi a BAIXA ADESÃO DOS ALUNOS as atividades } \\
\text { propostas. }\end{array}$ \\
\hline
\end{tabular}

Fonte: Desenvolvido pelos autores, 2020.

Os relatos apresentados pelos estagiários apontam aspectos positivos e negativos sobre a experiência de estágio remoto, principalmente em se tratando da participação das crianças e adolescentes nas atividades propostas. Um aspecto negativo a ser considerado se refere à baixa adesão dos estudantes em acompanhar as atividades, mesmo com todo o esforço dos professores em incentivar e acolher, por meio de atividades em diferentes formatos, formas de entrega em diversos canais de comunicação e até mesmo presencialmente para as famílias, em casos em que não havia acesso on-line - entregas de material impresso a cada 15 dias.

Por outro lado, foi possível identificar aspectos positivos no estágio remoto, que, apesar da frustração em não estarem presentes em sala de aula observando a rotina e a dinâmica escolar, além do aprendizado sobre diferenciadas formas de ensinar e aprender, também puderam ser testadas de maneiras criativas e bem-sucedidas com o uso das TDIC. Por exemplo, em um dos relatos, como o do estagiário 4, foi possível observar que o entendimento aprofundado sobre a experiência do estágio foi significativo, principalmente na leitura atenta dos documentos do estágio e nos momentos de socialização em grupo de WhatsApp, em que pôde tirar suas dúvidas. Como pode ser visto no relato do Quadro 1, tal estagiário, em especial, teve muita dificuldade em 
compreender e diferenciar termos importantes da prática pedagógica; mas afirma que, mesmo sendo muito desafiadora, a experiência do estágio contribuiu para trazer entendimento para suas dúvidas e ainda mostrou a importância da resiliência e adaptação no exercício da docência, além da capacidade de se reinventar a partir dos desafios enfrentados na prática.

Outra experiência significativa no estágio remoto foi do estagiário 3, que conseguiu abordar a temática atual do coronavírus e elaborou junto com os estudantes um modelo em 3D do vírus utilizando materiais que os alunos tinham em casa, como pode ser visto em seu relato no Quadro 01. Nesse caso, o levantamento de informações a respeito da estrutura viral do SARS - CoV- 2, agente etiológico da COVID- 19, ministrado por meio de Power Point com explanação oral e análise de imagens e vídeos sobre o assunto, possibilitou uma ampla discussão sobre uma temática da realidade atual, vivenciada também nas escolas e, ao mesmo tempo, contemplou a abordagem de um tema de extrema relevância para os estudantes de ciências.

Os materiais didáticos digitais produzidos pelos estagiários tinham como temática: a Matéria e Energia; Vida e Evolução; Terra e Universo, e também apresentavam debates sobre Educação e Sustentabilidade com base nas diretrizes orientadas pela BNCC. Com isso, foram produzidos vídeos curtos para o YouTube, podcast - gravação em áudio dos textos impressos -, infográficos - para facilitar a leitura de textos longos e complexos e um quis - questionário online - para uma atividade avaliativa.

A compreensão de que as TDIC são uma tendência na educação, e que, cada vez mais, escolas e universidades irão se apropriar das tecnologias educativas digitais para propor modelos híbridos de ensino e aprendizagem, foram assuntos amplamente debatidos durante o estágio remoto, partindo de um olhar crítico e reflexivo sobre o papel do futuro professor de ciências, suas implicações e desafios em cenários atípicos.

Com base nas experiências vivenciadas, foi possível traçar diretrizes norteadoras desses cenários para realização do estágio remoto em tempos de pandemia a partir do uso intensivo das TDIC e do trabalho colaborativo remoto com a escola.

\subsection{Diretrizes para o Estágio Remoto no Ensino de Ciências}

As diretrizes apresentadas nesta pesquisa representam um contexto singular do estágio remoto para o ensino de Ciências Biológicas desenvolvido na UDESC/CEAD, baseadas nos relatos de experiência realizados em um período de tempo e em uma situação atípica de pandemia. Por isso, essas orientações podem auxiliar professores, educadores, gestores e coordenadores sobre as ações a serem tomadas e as principais diretrizes para o estágio remoto em situações como as apresentadas.

Diante do exposto foi possível identificar e propor diretrizes para realização do estágio remoto em tempos de pandemia, conforme apresentado no Quadro 2:

\section{Quadro 2: Diretrizes para o estágio remoto}




\begin{tabular}{|c|c|}
\hline DIRETRIZES & LINHA DE AÇÃO \\
\hline Letramento Digital & $\begin{array}{l}\text { Os (as) estagiários (as) devem estar familiarizados com as tecnologias digitais } \\
\text { disponíveis para o Ensino de Ciências, para isso deve-se fazer um diagnóstico } \\
\text { prévio para saber os níveis de letramento digital, e se for o caso propor } \\
\text { capacitações no uso das TDIC. }\end{array}$ \\
\hline $\begin{array}{l}\text { Produção de } \\
\text { materiais didáticos }\end{array}$ & $\begin{array}{l}\text { A prática deve estar vinculada ao planejamento, ao objetivo de aprendizagem e } \\
\text { à produção dos materiais e recursos didáticos digitais e impressos, abrangendo a } \\
\text { diversidade da turma na escola. É necessário considerar que alguns estudantes } \\
\text { na escola podem não ter acesso aos recursos e materiais digitais, por isso deve- } \\
\text { se considerar opções variadas em outros formatos como o impresso. }\end{array}$ \\
\hline $\begin{array}{l}\text { Observação a } \\
\text { Distância }\end{array}$ & $\begin{array}{l}\text { A comunicação e a mediação pedagógica devem estar fundamentadas na } \\
\text { observação e no olhar atento da professora referência sobre a dinâmica da turma } \\
\text { em situação de isolamento. O estagiário precisa criar uma estratégia de } \\
\text { comunicação e interação intensiva durante o estágio com a professora referência } \\
\text { em momentos síncronos e assíncronos. }\end{array}$ \\
\hline Acesso ao AVA & $\begin{array}{l}\text { Para que o estágio se efetive de forma plena e com qualidade, os estagiários } \\
\text { devem ter amplo acesso ao AVA da turma em que está realizando o estágio, bem } \\
\text { como a todo canal de comunicação possível para acompanhamento, observação } \\
\text { participante e intervenção pedagógica efetiva e aproximada do estudante. }\end{array}$ \\
\hline $\begin{array}{l}\text { Adaptação e } \\
\text { flexibilização }\end{array}$ & $\begin{array}{l}\text { A avaliação do processo de estágio deve ser realizada a partir das observações da } \\
\text { professora referência, no caso de não haver acesso ao AVA para o } \\
\text { acompanhamento dos estudantes na escola. As atividades e avaliações devem } \\
\text { ser adaptadas de acordo com as realidades e os contextos da escola, } \\
\text { necessidades dos estudantes, família e comunidade. As sequências didáticas } \\
\text { podem não ser as mesmas e os prazos também. }\end{array}$ \\
\hline Inovação Pedagógica & $\begin{array}{l}\text { É recomendado trabalhar a criatividade e a inovação na produção dos materiais } \\
\text { didáticos digitais em multiplataformas e formatos, a fim de motivar e engajar o } \\
\text { estudante, minimizando a baixa adesão nas disciplinas e na participação. }\end{array}$ \\
\hline $\begin{array}{c}\text { Docência } \\
\text { Compartilhada }\end{array}$ & $\begin{array}{l}\text { Deve-se atuar em equipe de forma integrada e interdisciplinar com a professora } \\
\text { referência e os estudantes, gerenciando as atividades on-line, as entregas e } \\
\text { devolutivas do processo de ensino e aprendizagem. }\end{array}$ \\
\hline $\begin{array}{c}\text { Acompanhamento e } \\
\text { Feedbacks }\end{array}$ & $\begin{array}{l}\text { Deve-se ter acesso a todos os canais de comunicação para acompanhar e apoiar } \\
\text { o estudante de forma remota (síncrona ou assíncrona) e obter um retorno } \\
\text { qualitativo dos estudantes em um processo de retroalimentação da comunicação } \\
\text { e interação entre professor e estudante e vice-versa. }\end{array}$ \\
\hline
\end{tabular}

Fonte: Desenvolvido pelos autores, 2020.

As linhas de ação para o estágio remoto representam possibilidades significativas de planejamento e atuação, considerando que cada situação possui suas especificidades e diferentes resultados. Um ponto sensível nesse processo é o acesso - muitas vezes burocrático - 
dos estagiários ao AVA da escola, fundamental para facilitar suas ações investigativas e práticas pedagógicas, mantendo o isolamento social. Esse acesso possibilita a gestão educativa dos materiais e recursos didáticos, as diversas e enriquecedoras formas de comunicação, interação e a prática criativa e inovadora de mediação pedagógica.

Um aspecto relevante a ser considerado no estágio remoto se refere à docência compartilhada e ao incentivo ao trabalho colaborativo entre os estagiários e o professor referência, no sentido de apoiar a codocência a partir do acompanhamento dos estudantes nos diversos canais de comunicação da escola, na motivação entre os grupos de estudos e devolutivas das atividades propostas.

É importante reforçar que as diretrizes para o estágio remoto sejam variadas e flexíveis de modo a atender cada realidade vivenciada, que vão desde espaços escolares com professores já habilitados para o uso crítico e criativo das TDIC e infraestrutura tecnológica de alto nível, até escolas menos favorecidas que necessitam de incentivos e investimentos na formação de seu corpo docente e infraestrutura, para que o Ensino Remoto possa se concretizar, permitindo a inclusão e adesão de todos os sujeitos envolvidos no processo de ensino e aprendizagem.

\section{CONSIDERAÇÕES FINAIS}

Diante de uma realidade atípica e inédita ocasionada pela pandemia, apesar das adversidades e obstáculos encontrados no caminho, pode-se considerar que essa experiência de estágio remoto se constituiu como uma jornada de aprendizado com resultados tanto positivos quanto negativos, os quais foram evidenciados e debatidos.

Ao mesmo tempo em que os estagiários puderam aprender sobre planejamento docente, plano de aula, sequência didática e produção de materiais didáticos digitais, também puderam compreender o quão fundamental é o contato presencial para o aprendizado e motivação de crianças e adolescentes.

O cenário aqui apresentado reforçou as dificuldades encontradas pelos professores nas escolas quanto à participação e às devolutivas das atividades propostas. Muitos estudantes não aderiram ao Ensino Remoto por não conseguirem acompanhar as aulas on-line ou mesmo se comunicar em grupo com a professora, devido, principalmente, à falta de uma infraestrutura mínima tecnológica de apoio ao aprendizado tanto nas escolas como nos lares. Tal situação reforça a demanda por políticas públicas que garantam a inclusão digital de toda a sociedade e uma formação para o uso crítico e criativo das TDIC desde a Educação Infantil.

De qualquer forma, a partir de um trabalho hercúleo, sobretudo dos professores, o cenário que se vislumbra explicitou o uso criativo e inovador das TDIC na educação. É fato que as práticas e metodologias educativas, cada vez mais, estão se apropriando de forma positiva e qualitativa das TDIC nas escolas e instituições de Ensino Superior, e que, provavelmente, com a situação de isolamento vivenciada no ano de 2020, muitas escolas, gestores e educadores passarão por um processo de ressignificação de seus métodos de trabalho e planejamento de suas aulas presenciais com apoio das tecnologias digitais tão presentes na sociedade contemporânea. Ainda assim, para que isso ocorra de forma efetiva, tal processo deve vir acompanhado pela criação de 
políticas públicas que garantam a inclusão digital de toda a sociedade, uma infraestrutura tecnológica adequada em todas as escolas e a valorização e qualificação do trabalho docente.

A experiência do estágio remoto representou para o estudante de licenciatura em Ciências Biológicas uma oportunidade de atuação profissional em campo, o que possibilitou realizar um trabalho de articulação e síntese entre teoria e prática no âmbito das TDIC em um aprendizado inovador do ponto de vista do planejamento pedagógico.

Sendo assim, o cenário de pandemia propiciou também o repensar do papel das TDIC, no sentido de buscar estratégias que pudessem promover a inclusão e a emancipação dos estagiários envolvidos no processo formativo. Isso demandou uma leitura crítica deste contexto e do real potencial dessas tecnologias, em uma educação midiática e digital, cada vez mais presente e disseminada nas instituições de ensino.

\section{REFERÊNCIAS}

ARRUDA, E. P. Educação remota emergencial: elementos para políticas públicas na educação brasileira em tempos de Covid-19. Em Rede-Revista de Educação a Distância, Porto Alegre, v. 7, n. 1, p. 257-275, 2020. Disponível em: https://www.aunirede.org.br/revista/index.php/emrede/article/view/621. Acesso em: 08 set. 2020.

BRASIL. Ministério da Educação. Instituto Nacional de Estudos e Pesquisas Educacionais Anísio Teixeira. Indicadores Educacionais.. 2019. Disponível em: https://www.gov.br/inep/pt-br/acesso-ainformacao/dados-abertos/indicadores-educacionais. Acesso em: 06 out. 2020.

HODGES, C. et al. The difference between emergency remote teaching and online learning. EDUCAUSE Review. 27 mar. 2020. Disponível em: https://er.educause.edu/articles/2020/3/the-difference-betweenemergency-remote-teaching-and-online-learning. Acesso em: 11 maio 2020.

INSTITUTO BRASILEIRO DE GEOGRAFIA E ESTATÍSTICA (IBGE). Pesquisa Nacional por Amostra de Domicílios Contínua (PNAD). Acesso à Internet e à televisão e posse de telefone móvel celular para uso pessoal 2018. Rio de Janeiro: IBGE, 2020. Disponível em:

https://biblioteca.ibge.gov.br/visualizacao/livros/liv101705_informativo.pdf. Acesso em: 06 out. 2020.

LAPA, A. B.; BELLONI, M. L. Educação a distância como mídia-educação. Perspectiva, Florianópolis, v. 30, n. 1, p. 175-194, jan./abr. 2012. Disponível em:

https://periodicos.ufsc.br/index.php/perspectiva/article/view/2175-795X.2012v30n1p175. Acesso em: 06 out. 2020.

LEONEL, A. A. Formação continuada de professores de Física em exercício na rede pública estadual de Santa Catarina: lançando um novo olhar sobre a prática. 2015. Tese (Doutorado em Educação Científica e Tecnológica) - Universidade Federal de Santa Catarina, Florianópolis, 2015. Disponível em:

https://repositorio.ufsc.br/xmlui/bitstream/handle/123456789/169502/340342.pdf?sequence=1\&isAllowe $\mathrm{d}=\mathrm{y}$. Acesso em: 06 out. 2020.

LIMA, M. S. L.; PIMENTA, S. G. Estágio e docência: diferentes concepções. Poíesis Pedagógica, Catalão, v. 3, n. 3-4, p. 5-24, 2006. Disponível em: https://www.revistas.ufg.br/poiesis/article/view/10542. Acesso em: 06 out. 2020.

PIMENTA, S. G.; LIMA, M. S. L. Estágio e docência. 5. ed. São Paulo: Cortez, 2010. 
SENHORAS, E. M. Coronavírus e Educação: análise dos impactos assimétricos. Boletim de Conjuntura (BOCA), Boa Vista, v. 2, n. 5, Boa Vista, 2020. Disponível em:

https://revista.ufrr.br/boca/article/view/Covid-19Educacao. Acesso em: 04 dez. 2020.

WEFFORT, M. F. Educando o olhar da observação: aprendizagem do olhar. In: WEFFORT, M. F.

Observação, registro, reflexão. São Paulo: Espaço Pedagógico, 1997. Disponível em:

https://blogproinfanciabahia.files.wordpress.com/2013/03/educando-o-olhar-madalena-freire.pdf. Acesso em: 04 dez. 2020.

ZIMMERMANN, E. E.; BERTANI, J. A. Um novo olhar sobre os cursos deformação de professores. Caderno Catarinense de Ensino de Física, Florianópolis, v. 20, n. 1, p. 43-62, abr. 2003. Disponível em:

http://www.periodicos.ufsc.br/index.php/fisica/article/view/6563/6047. Acesso em: 04 dez. 2020. 